\title{
Filmowy zapis Arabskiej Wiosny
}

\author{
MAŁGORZATA RADKIEWICZ
}

Termin Arabska Wiosna odnosi się do wydarzeń, jakie miały miejsce w krajach Afryki Północnej oraz na Bliskim Wschodzie w 2011 i 2012 r. Na skutek masowych protestów doszło wówczas do upadku autorytarnych rządów: Zin el-Abidin Ben Alego w Tunezji (14 stycznia), Hosniego Mubaraka w Egipicie (11 lutego), Mu'ammara al-Kaddafiego w Libii (23 sierpnia) oraz Alego Abdullaha Saleha w Jemenie. Rewolucyjne działania objęły niemal cały świat arabski, od Maroka po Bahrajn i Syrię, w jednych krajach doprowadzily do obalenia reżimów, w innych do aktywizacji i umocnienia się opozycji. Ani w Jemenie, ani w Syrii nie udało się pokojowo zakończyć manifestacji, które stały się początkiem wyniszczających konfliktów zbrojnych, w 2019 r. wciąż dalekich od zakończenia. Zdaniem obserwatorów i badaczy, tym, co wyróżnia Arabską Wiosnę na tle ruchów protestacyjnych w innych krajach, jest jej intensywność i gęstość, zwłaszcza w roku 2011, opisywanym jako szczytowy okres polityki spornej albo faza zaognionego konfliktu, zarówno zorganizowanego, jak i niezorganizowanego ${ }^{1}$.

\section{Geneza i konteksty}

Jak zwraca uwagę Natalia Bahlawan, nazwa Arabska Wiosna - często budząca kontrowersje - łączyła analogię do europejskiej Wiosny Ludów z cyklem kalendarzowym, co miało prawdopodobnie sugerować naturalność i nieuchronność wydarzeń, które zwłaszcza dla Zachodu, były dość niespodziewane. W momencie upadku kolejnych reżimów świat odczuwał wręcz konsternację wynikającą między innymi z tego, że poprzedzająca walki ,arabska epoka lodowcowa" uznana została za klimat typowy tego regionu ${ }^{2}$. Równocześnie rozbudowane określenie Arabska Wiosna Ludów - pojawiające się zwłaszcza w pierwszych relacjach - służyło w dużej mierze podkreśleniu „oddolnego" charakteru wydarzeń oraz ich społecznych uwarunkowań i motywacji. Za symboliczny początek fali protestów przyjmuje się 4 stycznia 2011 r. - dzień śmierci 26-letniego Tunezyjczyka Mohameda Bouaziziego, który zmarł w wyniku poparzeń i ran odniesionych 17 grudnia 2010 r. podczas aktu samospalenia. Desperacki gest młodego mężczyzny przeciwko niesprawiedliwości i poniżeniu, jakiego doznał, gdy urzędnicy zarekwirowali mu towary, którymi handlował, stał się impulsem dla arabskich społeczeństw, by wyrazić sprzeciw wobec panującego systemu. Nadine Sika zauważa w analizie egipskich manifestacji, że stojące za nimi nowe ruchy społeczne miały raczej charakter świecki, a stawiane żądania dotyczyły w dużej mierze egzystencji ludzi i życiowych realiów. Rewolucjoniści 
w swoich hasłach przywoływali najczęściej idee: praw człowieka, sprawiedliwości społecznej, wolności i godności ${ }^{3}$.

Nacisk na „ludowość” Arabskiej Wiosny widoczny jest w poświęconych jej filmach fabularnych i dokumentalnych, ukazujących jednostkowy, prywatny wymiar wydarzeń. Oryginalność egipskich tytułów - Ostatnie dni miasta (reż. Tamer El Said, 2016); Coming Forth by Day (reż. Hala Lofty, 2012) - polega na rezygnacji z bezpośredniego przedstawiania Arabskiej Wiosny na rzecz eksponowania podmiotowości bohaterów, ich odczuć i przemyśleń. W obu filmach dokonano przesunięcia akcentów czasowych (akcja toczy się przed wybuchem rewolucji) oraz przestrzennych (z placów i ulic do wnętrza domów). W przypadku filmów o Syrii - Powrót do Homs (reż. Talal Derki, 2013); W czterech ścianach życia (reż. Philippe Van Leeuw, 2017); Ostatni w Aleppo (reż. Feras Fayyad, 2017) - dzieje się zgoła odwrotnie. Perspektywa prywatna i publiczna zostają nierozerwalnie splecione, jakby po wybuchu protestów istniała tylko jedna sfera egzystencji, a każdy pojedynczy człowiek musiał ponosić konsekwencje politycznych decyzji i działań. Twórcy filmowi sięgają po syryjskie wydarzenia oddalone od siebie czasowo, o różnym napięciu i nacechowaniu emocjonalnym (początek rewolucji, kolejne miesiące i lata walk), układając je w dramatyczną relację.

Obecność subiektywnej, często bardzo osobistej perspektywy w filmach o Arabskiej Wiośnie sprawia, że ich poetyka może budzić skojarzenia ze zindywidualizowanymi obrazami rewolucji, jakie od samego początku pojawiały się w mediach społecznościowych. Z amatorskich zdjęć i filmowych nagrań z krajów arabskich wyłaniało się całe spektrum ludzkich doświadczeń związanych z przebiegiem protestów i z ich konsekwencjami. Wielu komentatorów Arabskiej Wiosny używało nawet popularnego określenia, że była to „Facebookowa Rewolucja”, w upraszczający sposób kojarząc masowość społecznych wystąpień z globalnymi mediami jako środkiem mobilizacji. Jednak badacze społeczni i medialni nakazywali ostrożność w postrzeganiu i diagnozowaniu wypadków przez pryzmat przekazów internetowych. Zaznaczali za to konieczność analizy politycznych okoliczności wpływających na taką a nie inną aktywność w mediach społecznościowych oraz ich zróżnicowane role w różnych państwach arabskich. Jak zauważyła Lisa Anderson, kluczem do protestów nie była technika, ale sposób, w jaki rezonowała ona w różnorodnych kontekstach lokalnych ${ }^{4}$. Natomiast Pippa Norris przypominała, że sieć społecznej współpracy zawsze była dla Arabów, jak i dla wszystkich ludzi, niesłychanie ważna, i to znacznie wcześniej niż wynaleziono Internet ${ }^{5}$. Jej zdaniem, w przypadku Arabskiej Wiosny media społecznościowe mogły służyć ułatwianiu i podtrzymaniu działań, ale raczej jako jeden z wielu kanałów komunikacji, a nie podstawowy napęd niepokojów, zwłaszcza wobec wywołujących największy sprzeciw czynników: korupcji, niesprawiedliwości, represji.

Podejście do amatorskich i profesjonalnych przekazów medialnych czy filmowych właśnie w kategoriach międzyludzkiej komunikacji pozwala dostrzec ich wartość jako zapisu historii osób i społeczności uwikłanych w wydarzenia Arabskiej Wiosny. Subiektywna perspektywa przyjęta przez twórców/rejestratorów zmusza do przeniesienia uwagi ze świata wielkiej polityki na biografie i losy konkretnych ludzi. Równie osobistym kanałem informacji o Arabskiej Wiośnie łączącym relacje faktograficzne $\mathrm{z}$ autorskimi komentarzami pozostaje twórczość 
literacka Samar Yazbek, syryjskiej pisarki i dziennikarki, aktywistki i działaczki na rzecz praw kobiet. W 2012 r. ukazała się jej książka $A$ Woman in the Crossfire: Diaries of the Syrian Revolution ${ }^{6}$, w której opowiedziała o swoim pobycie w Damaszku podczas wybuchu rewolucji oraz o rozmowach z jej uczestnikami. Wcześniej swoje notatki udostępniała w Internecie, czym naraziła się władzom, które poddały ją przesłuchaniom, zastraszały i oczerniały w oczach publicznych jako wroga, zdrajcę i szpiega. Zanim zmuszono ją do wyjazdu z kraju, przez cztery miesiące miała szansę śledzić rozwój wydarzeń oraz spowodowane nimi przemiany w ludzkich postawach i nastrojach. Prowadzone zapiski nie miały charakteru uporządkowanej relacji, były raczej formą wyrażenia subiektywnych odczuć związanych najpierw z euforią, a potem ze strachem i coraz bardziej wszechobecną śmiercią. Pisanie z punktu widzenia uczestniczki pozwoliło autorce uchwycić społeczne aspekty Arabskiej Wiosny, co najsilniej zaznaczyło się we fragmentach poświęconych pomaganiu rannym demonstrantom, opiekowaniu się dziećmi, których rodzice zostali aresztowani, oraz pomocy kobietom starającym się podtrzymać rytm rodzinnego życia.

Rafik Schami we wstępie do książki Yazbek nazwał ją aktywnym świadkiem ${ }^{7}$, obdarzonym i zmysłem dziennikarskim, i umiejętnością plastycznego opisywania rewolucji, w której uczestnictwo wiązało się z nieustannym ryzykiem. Jeszcze większe ryzyko ponosiła Yazbek w sierpniu 2012 r., lutym 2013 r. oraz na przełomie lipca i sierpnia 2013 r., gdy trzykrotnie przedzierała się do pogrążonego w wojnie kraju, by pomóc ofiarom i wesprzeć przyjaciół. W zapiskach z kolejnych przepraw do pękniętego serca Syrii pokazała sytuację, w której rewolucyjny zapał zamieniał się w zdeterminowaną walkę. Dlatego publikację swoich materiałów zadedykowała męczennikom rewolucji syryjskiej ${ }^{8}$, wyznając na początku: Piszę zdrętwiałymi palcami. (...) Istnieję w prawdziwym świecie, ale pisząc o tym, zaczynam zanikać. (...) Oto moje drugie świadectwo syryjskiej masakry. (...) Robię to dla was. Moge tylko przywotać was w pamięci i uczynić z waszych historii kolumny sięgajace nieba. Piszę dla was: zdradzonych ${ }^{9}$.

Wyznacznikiem perspektywy przyjętej przez Yazbek pozostaje indywidualna pamięć i emocjonalne zaangażowanie w wydarzenia. Przygotowując książkę A Woman in Crossfire, otwarcie przyznała, że nie miała zamiaru tworzyć dokumentacji syryjskiego powstania. Oświadczyła, że prowadzone dzienniki sa po prostu stronami, na których polegałam podczas tych dni, by zmierzyć się ze strachem i panika, a także by obudzić trochę nadziei. Ale wszystkie sa prawdziwe, odnosza się do realności, i nie sa efektem imaginacji ${ }^{10}$. Reżyserzy filmowi, mimo że opierali się głównie na swojej wyobraźni, również musieli zmierzyć się z realiami Arabskiej Wiosny, co wpłynęło jeśli nie na samą fabułę, to na pewno na jej wydźwięe i sposób interpretacji.

\section{Egipska rewolucja}

Bohaterem filmu Tamera El Saida Ostatnie dni miasta (Akher ayam el Madina, 2016) jest Khalid, który ma ambicję stworzenia dokumentalnego eseju o Kairze, oddającego jego atmosferę oraz dynamikę życia. Jako twórcy zależy mu ponadto na uchwyceniu społecznych i politycznych napięć wyrażających ducha czasów. Okiem kamery przygląda się więc najbliższemu otoczeniu, rejestruje drobne 
uliczne zdarzenia, spotkania i rozmowy z przyjaciółmi. Wizualnym obserwacjom Khalida towarzyszą jego komentarze, refleksje i wspomnienia, podkreślające wrażenie przemijalności, poczucia końca i nieodwracalnej straty. Nostalgiczny nastrój wynika po części z doświadczeń osobistych - konieczności opuszczenia dotychczasowego mieszkania, braku kontaktu z bliskimi, a także ze świadomości procesów zachodzących równolegle w ludzkich biografiach oraz w strukturze miasta jego architekturze, stylu i kulturze. Rozmowy z przyjaciółmi pozwalają bohaterowi dzielić się wrażeniami i wątpliwościami, po czym przedyskutować je i porównać z odczuciami przyjaciół, zastanawiających się nad swoimi perspektywami w kraju i nad ewentualną emigracją. Dla przybyłego z Iraku Hassana najważniejsze jest inne miasto - Bagdad, do którego może powracać wyłącznie we wspomnieniach. W efekcie, jak tłumaczy znajomym, miejsce to traci dla niego swoją konkretność, stając się raczej odczuciem.

Khalid nigdy nie musiał opuszczać Kairu z powodu wojny, ale jego relacje z miastem są równie skomplikowane i emocjonalne, co można wyczuć w długich ujęciach pokazujących, jak przygląda się miejskim plenerom, dachom domów za oknem opuszczanego mieszkania, ulicom i tłumom przechodniów. Z punktu widzenia mieszkańca-obserwatora kręci on również materiały do swojego projektu, wciąż dalekiego od finalizacji. W filmie pojawiają się sceny pokazujące niezdecydowanie bohatera-reżysera co do sposobu montażu i ostatecznego kształtu zarejestrowanych obrazów. Podobne wątpliwości musiał mieć także Tamer El Said, który rozpoczął filmowanie w 2007 r., pragnąc stworzyć wielowątkowy, zróżnicowany stylistycznie i formalnie obraz Kairu. Jak podkreślił w rozmowie z Joffreyem Speno ${ }^{11}$, to miasto go ukształtowało, w nim się wychował, dlatego zależało mu na uchwyceniu jego skomplikowanej, wielowarstwowej i wyrafinowanej struktury w stanie rozpadu. Paradoksalnie, zdjęcia do Ostatnich dni miasta zakończyły się tuż przed wybuchem Arabskiej Wiosny, co sprawało, że autorska melancholijna wizja „końca” egipskiej metropolii stała się nieoczekiwanie zapowiedzią rewolucyjnych przemian.

Konsekwentne postanowienie Tamera El Saida, by uchwycić duszę miasta, sprawiło, iż nie mógł pozostać obojętny na wydarzenia rewolucji, zwłaszcza na jej początku. Jak przyznał: Chciałem przeżyć ten moment $i$ być jego częścia, jako że była to chwila, w której moje państwo zmieniało się na zawsze ${ }^{12}$. Dalsze wypadki, jak również kłopoty finansowe, wydłużyły proces twórczy, a jednocześnie zmusiły reżysera do przemyślenia na nowo podjętych wątków i problemów, zwłaszcza że w zmieniających się realiach zyskały one odmienny wymiar. Na ostateczny kształt Ostatnich dni miasta wpłynęło przekonanie autora, iż choć nie mógłby skończyć tak osobistego filmu bez uwzględnienia tego, co działo się wokół, powinien jednak pozostać wierny wyjściowej koncepcji. Dlatego mimo sugestii producentów nie zgodził się, by na końcu opowieści dodać scenę z masowego buntu w Kairze. Nawet przy braku bezpośrednich odniesień do Arabskiej Wiosny nakręcony wcześniej materiał zyskał historyczną ramę, wyznaczoną przez dwa momenty wpisane w cykl realizacji: przed protestami i po protestach oraz związanych z nimi zamieszkach. W ujęciu Tamera El Saida: Ten film nie jest o rewolucji, jest o tej chwili przed. Starałem się uchwycić nasze odczucia w Egipcie sprzed rewolucji-jakby miało się zdarzyć coś wielkiego. Nie wiedzieliśmy co, ale jasne było to, że nie mogliśmy kontynuować dotychczasowej pracy, kiedy $w$ kraju się gotowało ${ }^{13}$. 
Napięcie odczuwane w Egipcie przez reżysera i bohaterów jego filmu narastało w krajach arabskich wraz z pogłębiającą się biedą oraz niezadowoleniem społecznym, lekceważonym przez lokalne władze i świat. Marcin Tarnawski pisząc o międzynarodowych implikacjach Arabskiej Wiosny, zwrócił uwagę, że wydarzenia w regionie przyczyniły się do weryfikacji powszechnych, opartych na stereotypach przekonań na temat świata arabskiego. Jedno z nich dotyczyło postrzegania Arabów jako społeczności, która nie wychodzi na ulicę, by protestować i domagać się swoich praw. Jak zaznaczył autor, przed rozpoczęciem protestów w Tunezji i Egipcie wielu ekspertów uznawało wręcz, że w krajach tych ani reformy, ani zmiany nie są konieczne, bowiem nie ma na nie zapotrzebowania społecznego ${ }^{14}$. Wydarzenia pokazały, iż było zgoła inaczej. Inne, równie błędne przekonanie dotyczyło odłożenia reform politycznych na przyszłość, by najpierw dokonać liberalizacji gospodarczej. Tymczasem korzyści z prywatyzacji w państwach arabskich odniosły jedynie elity polityczne i biznesowe, a większość społeczeństw nie odczuła poprawy swojego bytu.

Ilustracją dla tych zjawisk są sceny z Ostatnich dni miasta pokazujące różnice w statusie i stylu życia mieszkańców, nierówności ekonomiczne, bezdomność, a także wszechobecnych uzbrojonych żołnierzy czy widoczne w miejscach publicznych zakazy patrzenia na kobiety. Wśród zaobserwowanych przez bohatera sytuacji jest uliczna bójka, jest scena przemocy domowej wobec kobiety. Reżyser zaznaczył, że włączył je do swojego filmu nie po to, by kogokolwiek osądzać, ale raczej by postawić ważne dla siebie pytania. Pierwsze dotyczyło roli twórcy oraz jego prawa do filmowania podobnych zdarzeń, drugie - roli państwa, polityków, policji, religii w kreowaniu oficjalnej narracji, z którą sam nigdy się nie utożsamiał. Zastanawiając się, którą historię opowiedzieć i uczynić żywą, doszedł do wniosku, iż jako filmowiec powinien wspierać alternatywna narrację, zawierająca historie, jakie nigdy nie sq opowiadane ${ }^{15}$.

Film Ostatnie dni miasta można więc potraktować jako zapowiedź wydarzeń opisanych przez Ann M. Lesch w relacji z wczesnego etapu protestów, gdy 25 stycznia 2011 r. tysiące ludzi zebrało się na placu Tahrir - w symbolicznym centrum Kairu z ikoniczną figurą Saada Zaghlula, lidera egipskiej rewolucji z 1919 r. W poczuciu wspólnoty protestujący potępiali postawę służb bezpieczeństwa oraz ministra spraw wewnętrznych, śpiewając i wykrzykując hasła oraz żądania: aish (chleba), karama (godności), andhurriya (wolności) ${ }^{16}$. Podobną atmosferę masowości i wspólnotowości ma scena manifestacji po obaleniu Mubaraka, pojawiająca się w zakończeniu filmu Morderstwo w hotelu Hilton (The Nile Hilton Incident, 2017) w reżyserii Tarika Saleha. Akcja rozgrywa się na tle wydarzeń poprzedzających wybuch Arabskiej Wiosny, co czyni z opowieści rodzaj fabularnego odpowiednika Ostatnich dni miasta. Zwłaszcza że ujawniane w policyjnym dochodzeniu okoliczności tytułowego morderstwa składają się na obraz skorumpowanego i zdegenerowanego świata, w którym wcześniej czy później musiało dojść do zamieszek. Jak piszą Javed Maswood i Usha Natarajan, wystąpienia przeciwko arabskim reżimom były napędzane przez wysoki poziom korupcji, nepotyzm, biedę i bezrobocie, a także sposób zarządzania i rozwoju, który przynosit korzyści elitom, ale nie powiódt się w przypadku większości ${ }^{17}$.

Policyjny dramat Tarika Saleha uzmysławia złożoność egipskiej sytuacji, kiedy doszło do protestów, odsłaniając stojące za nimi kwestie społeczne i polityczne: prze- 
kupność władz, różnice klasowe, ekonomiczne i etniczne oraz zbudowane na nich sieci zależności. Im dłużej główny bohater, policjant, zajmuje się sprawą zbrodni, tym mocniej odczuwa konieczność radykalnego rozstrzygnięcia lokalnych problemów. Paradoksalnie, w momencie, gdy próbuje dopominać się o sprawiedliwość społeczną, staje się ofiarą zbuntowanego thumu, którego obraz w końcowej sekwencji filmu odzwierciedla panujące w Egipcie napięcia. Dina Bishara zwraca uwagę na fakt, że choć rewolucja była spektakularnym zrywem i zachwiała egipskim reżimem, to jednak nie można zapominać o aktywistycznej działalności robotników, którzy przygotowali grunt dla Arabskiej Wiosny. Jak powiedział jej jeden z nich: Robotnicy nie przyłączyli się do rewolucji; rewolucja przyłaczyła się do robotników ${ }^{18}$.

Intensywność wydarzeń Arabskiej Wiosny sprawiła, że w serialu Nocny recepcjonista (The Night Manager, reż. Susanne Bier, 2014) to właśnie Egipt oraz kraje arabskie zastąpiły Karaiby i Amerykę Łacińską z powieści Johna le Carré z 1993 r., na której oparto scenariusz. Pierwszy odcinek rozgrywa się w 2011 r. w ogarniętym rewolucją Kairze, na którego ulicach trwają walki zakończone rezygnacją prezydenta Mubaraka. David Farr scenarzysta Nocnego recepcjonisty stwierdził w wywiadzie, że podczas pracy nad adaptacją powieści oczywiste było dla niego przeniesienie akcji we współczesne realia, choć zasadniczy problem pozostawał ten sam: eksploatacja innych części świata dla zysków Zachodu ${ }^{19}$. Zaznaczył przy tym, iż nie pragnął sformułować poważnego komentarza na temat zachodnich działań na Bliskim Wschodzie, bo adaptował przecież opowieść szpiegowską. Dużo jednak myślał o wydarzeniach w tym regionie, zwłaszcza że - jego zdaniem - bardzo dobrze wpisały się one w intrygę zaczerpniętą z książki le Carré, w którego pisarstwie przewijają się głębokie, niemal religijne idee zdrady, zaufania, wiary ${ }^{20}$.

W kairskich epizodach Nocnego recepcjonisty zaciera się granica między faktami a fikcją, co sprawia, że niesprawiedliwość i mechanizmy władzy funkcjonują niejako zgodnie z regułami gatunkowej konwencji, a nie politycznego życia we współczesnym świecie. Serialowa sekwencja z ulic Kairu wpisuje się w serię medialnych obrazów, w których rozmywają się indywidualne rysy ludzi i siła ich dramatów. Samar Yazbek ostro skomentowała w swojej książce medialne wizje, stwierdzając: To, co się dzieje, nie jest niczym nowym w historii ludzkości, z tym że teraz rozgrywa się na oczach catego świata - tryskajaca krew bruka nam ręce. Globalna machina medialna wyświetla nam barbarzyński film złożony z brutalnych obrazów, wciąż napływają kolejne uaktualnienia, które posyłają w niebyt kolejna ofiarę, gdy tylko pojawi się następna, i przyprawiaja o mdłości powtarzalnościa tej hekatomby. Widzowie konsumuja wiadomości i zaraz je wydalaja ${ }^{21}$.

Bohaterowie filmów Ostatnie dni miasta oraz Morderstwo w hotelu Hilton znajdują się w centrum miejskiego życia, mniej lub bardziej świadomie przyglądając się ludziom i sytuacjom, które za chwilę doprowadzą do wybuchu rewolucji. Natomiast w filmie egipskiej reżyserki Hali Lofty Coming Forth by Day (Al-khoroug lel-nahar, 2012) perspektywa zostaje odwrócona, a wszystko, co dzieje się w mieście, zostaje wyrzucone poza ramę kadru. Mimo braku odwołań do przewrotu, wyczuwa się w filmie gęstą, pełną napięcia atmosferę, podobną do tej, jaką wykreował w swoim obrazie Tamer El Said. U Lofty akcja rozgrywa się w kairskim mieszkaniu, do którego odgłosy ze świata zewnętrznego docierają w sposób przytłumiony albo wprost z ulicy, przez zasunięte zasłonami okna, albo z ekranu telewizyjnego. Izolacja i ograniczoność przestrzeni przekłada się na relacje między dwiema ko- 
bietami oraz sparaliżowanym mężczyzną pozostającym pod ich opieką. Podczas gdy żona codziennie wychodzi do pracy, córka pozostaje na miejscu i zajmuje się chorym ojcem, powtarzając pielęgnacyjną rutynę. Jedynie odwiedziny krewnego zakłócają ten monotonny rytm. Życie w wielkiej metropolii zostaje zredukowane do mikroświata mieszkania, którego klaustrofobiczną atmosferę podkreślają nieśpieszne ruchy kamery oraz przytłumione światło. Wrażeniu zamknięcia towarzyszy poczucie bezsilności, jakie odczuwają i matka, i córka wobec swojej sytuacji. W ich życiu nie dochodzi spektakularnego przewrotu ani rewolucyjnej zmiany, choć jako kobiety bez wątpienia reprezentują grupę społeczną, której byt i sytuację materialną mógłby poprawić tylko systemowy przewrót na miarę Arabskiej Wiosny.

Mottem filmu Coming Forth by Day jest stwierdzenie: Każdy idiota może zmierzyć się z kryzysem - to życie dzień za dniem cię zużywa, po czym rozwija się ono w serię pytań: Ci, którzy czerpia petna satysfakcję ze swoich ciał, nie potrafia ulegać. A ci, którzy nigdy tej satysfakcji nie mieli? Czy przetrwaja niewole samotności $i$ bezsilna akceptację tego, czego nie moga zmienić albo znieśc ${ }^{22}$. Żadna z bohaterek opowieści nie wychodzi protestować w przestrzeni publicznej, swoje żale i resentymenty wyrażają podczas rozmów toczonych w zaciszu domowym. W córce stopniowo narasta pragnienie wyzwolenia, lecz kiedy w końcu udaje się jej opuścić rodzinne mieszkanie, szybko przekonuje się, że miasto wcale nie jest przyjazne dla kobiet. W nieznanej okolicy, z której trudno się jej wydostać, bowiem taksówkarze nie chcą zabierać samotnej pasażerki, czuje się jeszcze bardziej osamotniona.

Hala Lofta, twórczyni niezależnych dokumentów, zaczęła pracę nad swoim fabularnym debiutem w 2007 r., ale projekt Coming Forth by Day zawieszono z przyczyn politycznych i udało się go dokończyć dopiero po egipskich wydarzeniach Arabskiej Wiosny. Jak wspomina, kairskie mieszkanie, w którym na powrót kręcono zdjęcia, wynajęto 24 stycznia 2011 r., a już następnego dnia, 25 stycznia, wszyscy dołączyli do demonstracji. Kilka dni później, 28 stycznia, służby bezpieczeństwa aresztowały większość ekipy, do końcowego etapu filmowania przystąpiono więc dopiero w lipcu $2011 \mathrm{r}$. Zdaniem reżyserki, te cztery lata przerwy sprawiły, że projekt stał się wręcz „aktem oporu” wobec polityki lekceważącej kwestie arabskich kobiet. Jej koncepcja filmu budzi skojarzenia z realizacją Chantal Akerman Jeanne Dielman, Bulwar Handlowy, 1080 Bruksela (1975), w manifestacyjny sposób skupionym na „niefilmowych” doświadczeniach kobiety egzystującej w przestrzeni domowej, zgodnie z rutyną codziennych zajęć. Hala Lofta nie pokazuje egipskiej Arabskiej Wiosny, ale w taki sposób przedstawia swoje bohaterki, by nie było wątpliwości, że i one mają powody i prawo do niezadowolenia. Zresztą Hania Sholkamy wyraźnie zaznaczyła w swojej analizie egipskiej rewolucji, iż była zaplanowana, przeprowadzona i wspierana zarówno przez mężczyzn, jak $i$ przez kobiety ${ }^{23}$. Zwróciła też uwagę na istniejące wcześniej ruchy protestacyjne, inicjowane przez działaczy na rzecz praw robotników i swobód obywatelskich dla obu płci.

Donia Maher grająca u Lofty córkę przyznała, że okres oczekiwania na wznowienie produkcji okazał się dla niej niezwykle przydatny w przepracowaniu roli. Gdy ponownie stanęła na planie, czuła się bardziej dojrzała, gotowa wczuć się w sytuację postaci i zrozumieć jej zachowanie, zwłaszcza gotowość do tłumienia gniewu oraz niezgody na swój los. Natomiast Salma El-Najjar wcielająca się 
w matkę - kobietę oddaną mężowi, choć w wyniku jego choroby coraz bardziej osamotnioną emocjonalnie - stwierdziła, że zafascynowała ją opowiadana w filmie historia czysta i bardzo egipska ${ }^{24}$. W jej mniemaniu, patrząc $\mathrm{z}$ arabskiej perspektywy: Nigdy tak naprawdę nie przygladamy się kobietom w kinie. (...) W prawdziwym życiu głównymi postaciami w świecie sa kobiety. (...) W tym filmie mamy historie dwóch kobiet. I nie sq one sportretowane w petnym blasku. Co jest $w$ tym specyficznie egipskiego? Osoba wspierajaca rodzine jest tu kobieta ${ }^{25}$. Aktorka doskonale zrozumiała taką sytuację, ponieważ sama żyła w podobnej, jako wdowa i opiekunka rodziców. W swojej bohaterce starała się ukazać cechy kobiet, których wysiłku nikt nie dostrzega, jak w przypadku pielęgniarek w szpitalach, choć to one stanowią większość personelu.

Do finalizacji projektu tak mocno skoncentrowanego na sprawach kobiet przyczyniła się nie tylko Arabska Wiosna, ale także fakt, że już w 2010 r. Hala Lofta założyła wraz ze swoimi współpracownikami - między innymi aktorką Donią Maher - niezależną firmę producencką Hassala Films (z arab. skarbonka). Jej celem jest wspieranie młodych artystów w realizacji wymarzonych projektów, m.in. przez bezpłatne udostpnianie im kamer i montażowni, a także zapewnienia pomocy w staraniach o dofinansowanie. W czerwcu 2011 r. Lofta otrzymała prestiżową nagrodę Katrin Cartlidge Foundation, przyznawaną filmowcom za kreatywność i podtrzymywanie w kinie ducha niezależności.

\section{Konflikt zbrojny w Syrii}

Niezależną produkcją miała być także opowieść o Arabskiej Wiośnie w Syrii, jaką reżyser Talal Derki postanowił zrealizować, gdy tylko doszło do wybuchu rewolucji. Po przyjeździe do Homs spotkał 19-letniego Abdula Basseta al-Saroota, który jako lokalna gwiazda futbolu stał się rozpoznawalnym, podziwianym i naśladowanym uczestnikiem wydarzeń. Pierwsze akty filmu Derki zostały zmontowane z materiałów, jakie zaraz po przyjeździe nakręcił producent Orwa Nyrabia oraz mieszkaniec miasta Ossama Al Homsi, nagrywający na swoim telefonie bieżące wydarzenia i przyjaciół, między innymi Basseta. W efekcie początkowe partie filmu wyprzedzają moment przyjazdu ekipy, pokazując euforię towarzyszącą społecznemu zrywowi, podjętemu z energią, entuzjazmem i nadzieją na szybkie zwycięstwo. W jednym z otwierających ujęć Basset niesiony na ramionach przez kolegów wykrzykuje antyreżimowe hasła i śpiewa pieśni. Jego zapał udzielał się innym, zwłaszcza że jako znany bramkarz wykorzystywał podczas demonstracji elementy rytuałów kibiców, na przykład tańca w kręgach, zbliżającego i wzmacniającego poczucie wspólnoty.

Rafik Schami we wstępie do książki Yazbek ${ }^{26}$ pisze o tym, iż nie zdawał sobie sprawy, jak zresztą wielu innych, z poziomu niezgody w społeczeństwie syryjskim, dopóki nie doszło do buntu. Wszystko zaczęło się w miejscowości Da’ra na południu Syrii, gdzie młodzi ludzie zaczęli protestować, pisząc na murach hasło: „Precz z korupcją!’. Manifestacje stały się wyrazem oporu wobec nadużywania władzy, skorumpowanych urzędników, wtącania do więzień i stosowania tortur. Pokojowe demonstracje pozwoliły wreszcie przemówić zwykłym obywatelom, którzy w geście solidarności wyszli na ulicę w setkach miejsc na terenie całego kraju. Jak zauważa Schami, początkowo protesty nie były wprost skierowane przeciwko 
prezydentowi Baszszarowi al-Asadowi, ale przeciw niesprawiedliwości, politycznym i gospodarczym nadużyciom. Tymczasem władze zareagowały na zryw społeczny zbrojną interwencją i strzałami, co spowodowało, że pojawiły się pierwsze ofiary, a ich pogrzeby przerodziły się w jeszcze tłumniejsze demonstracje.

W trakcie pobytu w Homs Derki oraz Nyrabia postanowili podążać z kamerą za swoimi bohaterami Ossamą i Bassetem. Z czasem stanowisko operatora powierzyli Kahtanowi Hassounowi, który jako drukarz nie miał zbyt dużego doświadczenia w pracy z kamerą, ale był jednym z najbardziej zaangażowanych aktywistów w swojej okolicy, a ponadto bliskim przyjacielem Basseta. Znajomość realiów oraz bezpośrednie uczestnictwo w rewolucji sprawiły, iż to właśnie Hassoun rejestrował wydarzenia na linii frontu w ostatniej fazie powstawania dokumentu w 2012 r., gdy ani reżyser, ani producent nie mogli przyjechać do ostrzeliwanego miasta. Twórcy Powrotu do Homs przyznają, że ich koncepcją i planem pracy całkowicie zawładnęły wydarzenia polityczne, zwłaszcza te z letnich miesięcy 2011 r., gdy nasiliła się przemoc syryjskiej armii w tłumieniu protestów. Wkroczenie wojsk do Homs doprowadziło do rozpoczęcia regularnych walk, w których Basset, Ossama i inni entuzjaści przemian stali się nieoczekiwanie bojownikami. Podobną historię wojskowej mobilizacji można odnaleźć w zapiskach Samar Yazbek, której jeden z mężczyzn zwierza się: Boże! Wyszedtem z wojska w styczniu 2011 roku. - powiedziat - Nawet nie zdążyłem się wyszaleć przed rozpoczęciem rewolucji. Wyszliśmy protestować jak wszyscy: byliśmy pokojowo nastawieni i domagaliśmy się tylko reform. Tak, przysięgam - dodat z uśmiechem. - Ale oni zabijali nas i aresztowali, i puszczali z dymem nasze domy ${ }^{27}$.

Dramatyzm opowieści narasta w Powrocie do Homs stopniowo, wraz z każdym wybuchem oraz kolejnymi ofiarami, wśród których dominują cywile, w tym także dzieci. Na skutek intensyfikacji działań zbrojnych jest coraz mniej czasu na opłakiwanie poległych, trudniej też udzielić medycznej pomocy wszystkim rannym. W przejmującej scenie postrzelenia Ossamy uderzająca jest bezsilność bohaterów, starających się pomóc przyjacielowi i jak najszybciej przetransportować go do szpitala. Podobne momenty poczucia bezradności i rozpaczy będą się w filmie pojawiać coraz częściej, towarzysząc nalotom i atakom. Jak ujęła to Samar Yazbek w swojej relacji „spod linii ognia”: W każdym razie jedynym zwycięzca w Syrii jest śmierć: nikt nie mówi o niczym innym. Wszystko jest względne i wątpliwe; można być pewnym wyłacznie tego, że śmierć zatriumfuje ${ }^{28}$.

Na oczach twórców dokumentu Homs przekształcało się w pole bitwy, z barykadami utrudniającymi poruszanie się i domami zamienionymi w posterunki ochotników. Dopełnieniem filmowej wizji mogą być wspomnienia Yazbek z pogrążającego się w walkach Damaszku, gdzie spędziła pierwsze tygodnie rewolucji. Konsekwencje radykalności wojskowej interwencji są już widoczne w notce z 25 marca 2011 r., gdy pisze wręcz o karnawale śmierci: Zwyczajne wyjście na ulicę oznacza możliwość śmierci; ta myśl mnie poraziła. (...) idziesz z przyjaciótmi demonstrować, wiedzac, że są tam snajperzy ze shużb bezpieczeństwa, mogacy cię zastrzelić w każdej chwili ${ }^{29}$. Dla mieszkańców Homs, tak jak i dla autorki zapisków, pozostanie w kraju oznaczało konieczność oswojenia się z warunkami życia w trakcie konfliktu zbrojnego, którego najcięższe fazy miały dopiero nadejść. Podczas powrotu do domu przez opustoszały bazar Yazbek obserwuje autokary wypełnione uzbrojonymi mężczyznami, czekającymi na włączenie ich do walki. O swoich odczuciach pisze: Teraz moge docenić 

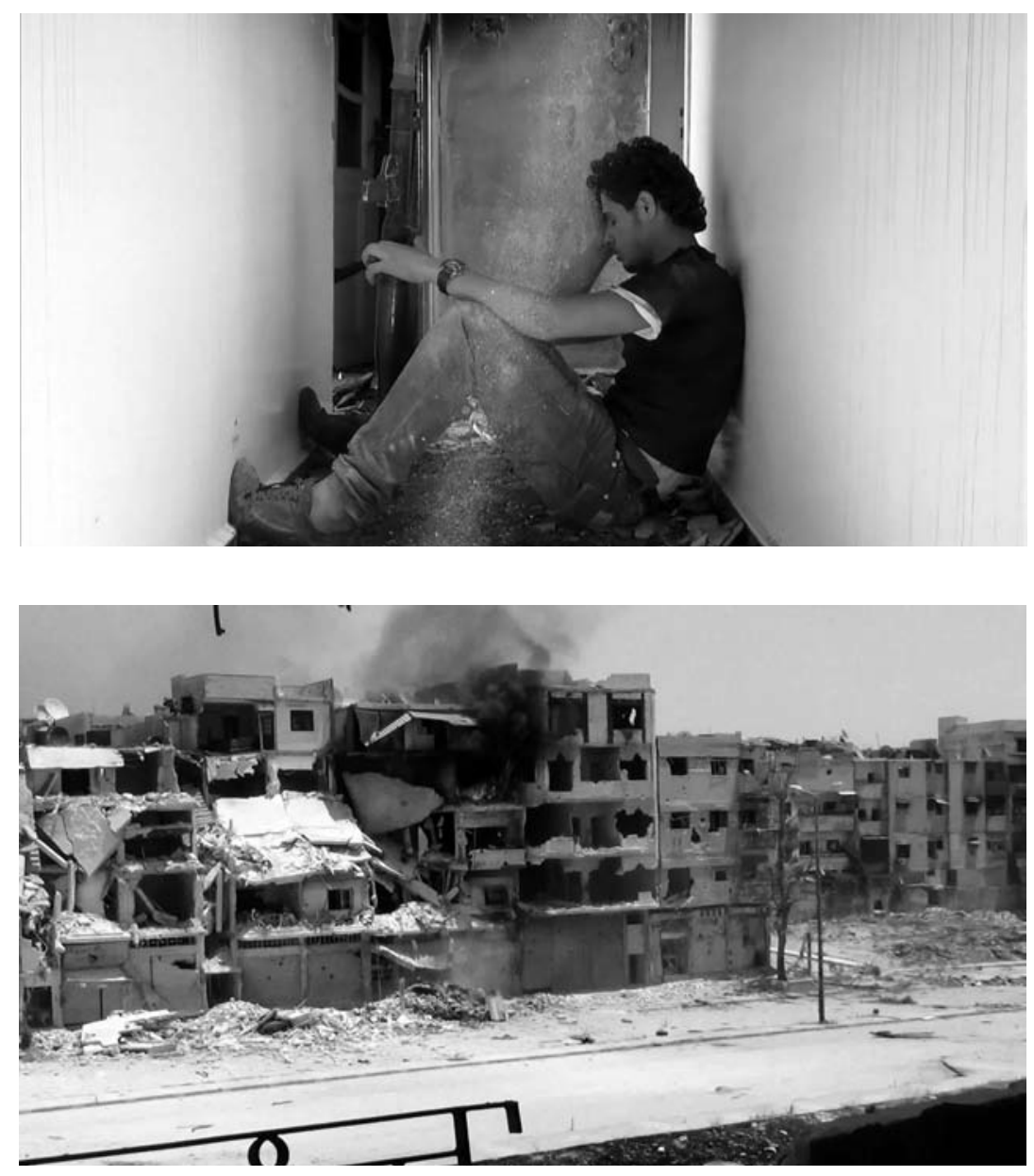

Powrót do Homs, reż. Talal Derki (2013)

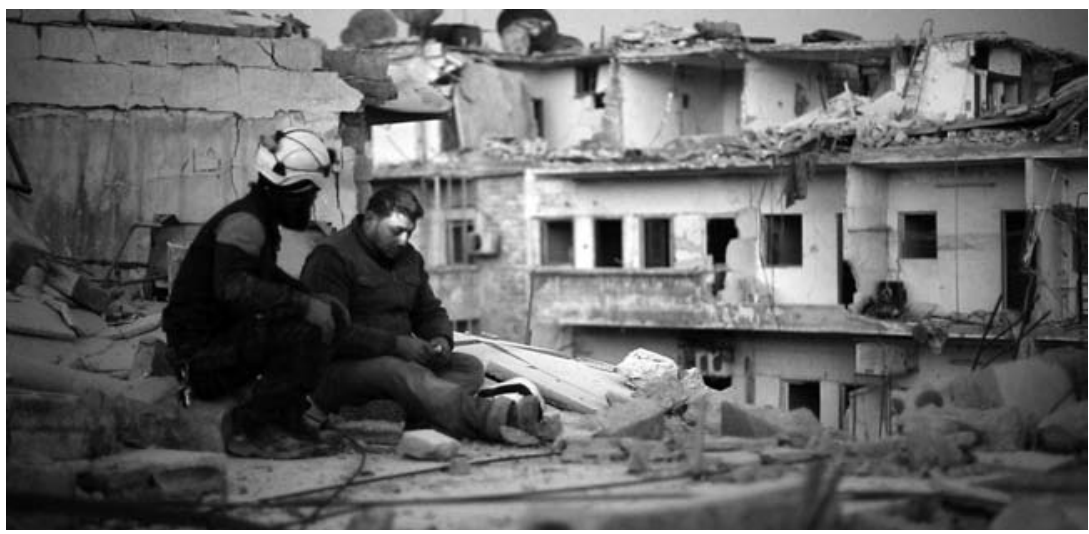

Ostatni w Aleppo, reż. Feras Fayyad (2017) 
znaczenie wyrażenia „petna napięcia cisza”. Styszałam to określenie już wcześniej, uważałam je bardziej za figure retoryczna niz faktyczny opis. W tych dniach w Damaszku potrafię zrozumieć , petna napięcia ciszę”, poprzez ludzkie oczy i ruchy ${ }^{30}$.

W podobnej pełnej napięcia ciszy twórcy Powrotu do Homs śledzili na bieżąco losy swoich bohaterów. W milczeniu obserwowali zdarzenia, w wyniku których z trudem uratowany Ossama we wrześniu 2012 r. został aresztowany w pobliżu granicy syryjsko-libańskiej i jego losy do końca pracy nad filmem pozostały nieznane. Ekipie nie udało się uzyskać informacji, czy w ogóle żyje. Jak stwierdził Nyrabia: Byt on przeciwny zbrojnej rewolucji, ale w oczach rezimu aktywista z kamera jest gorszy od tego, kto ma $w$ rękach broń ${ }^{31}$. Losy Ossamy i jego zaangażowanie w dokumentację rewolucji w Internecie mogłyby posłużyć za przykład w dyskusji na temat politycznego wymiaru szybkiej komunikacji o szerokim zasięgu oraz jej potencjalnego wpływu na faktyczną mobilizację do działania arabskich społeczności. Zdaniem badaczy, zawsze najpierw jest polityka ${ }^{32}$, bowiem to rozprzestrzeniające się działania polityczne, jakimi były masowe protesty, wywołały zmiany w wykorzystaniu mediów społecznościowych, a nie samo ich śledzenie. Równocześnie analitycy Arabskiej Wiosny podkreślają, że wraz z jej kolejnymi fazami wzrastało zapotrzebowanie na informację alternatywną wobec oficjalnych środków przekazu, a także na kanały nawiązywania kontaktów i dzielenia się doświadczeniami. Stąd popularność Internetu oraz mediów społecznościowych, z których korzystali także zagraniczni dziennikarze szukający bezpośrednich relacji $\mathrm{z}$ regionu.

Powrót do Homs również miał być bezpośrednim i alternatywnym przekazem, wymagającym fizycznego i emocjonalnego zaangażowania. Jego powstanie było związane z projektem nazwanym Baladi (z arab. mój kraj, moja ojczyzna), jaki w 2011 r. zainicjowała reżyserka i producentka Diana El Jeiroudi, nakłaniając syryjskich twórców do pracy pomimo niesprzyjających okoliczności, a jednocześnie starając się o zapewnienie im jak największego bezpieczeństwa. Talal Derki przyznał, że praca nad Powrotem do Homs zmieniła go w kategoriach artystycznych, przekonał się bowiem, iż filmowiec musi żyć wewnątrz filmu, który robi, cały czas będac obecnym, bez względu na wszystko, by udało się przekazać odpowiednie odczucia $^{33}$. Bliskość twórców wobec bohaterów jest wyczuwalna szczególnie we fragmentach pokazujących momenty ich bezsilności i zwątpienia w sens dalszej walki. Jedną z najbardziej przejmujących jest scena, w której Basset siedzi samotnie w wąskim korytarzu na wpół zawalonego domu, przygnębiony zniknięciem Ossamy, śmiercią większości przyjaciół oraz pogarszającą się sytuacją na froncie. W zmęczonym bojowniku nie ma nawet śladu początkowego optymizmu, wydaje się wręcz załamany, zwłaszcza że otwarcie przyznaje, iż nie ma już w sobie zapału. Mówi wprost: Mam dość, ale wie, że nie może się wycofać. Gdy reżyser pyta go, czy ta rewolucja się kiedykolwiek skończy, Basset gorzko się uśmiecha odpowiadając: Pewnie - oni nie sa nieśmiertelni. Mimo że siły zbrojne wypchnęły go i innych bojowników na peryferia Homs, postanawia wrócić do miasta i nadal walczyć. Z informacji dobiegających z Syrii wynika, że bohater filmu aktywnie uczestniczył w akcjach zbrojnych w północno-zachodniej części kraju aż do 2019 r. Jak doniosły media, były bramkarz syryjskiej drużyny piłkarskiej oraz ikona rewolucji zmarł 8 czerwca 2019 r. w tureckim szpitalu, w wyniku ran odniesionych w walce. 
Podczas rozmowy z Samar Yazbek jeden z syryjskich wojowników wyznał: $W$ trakcie walki przestajemy być ludźmi. To sprawa życia lub śmierci-zaśmiat się ironicznie. - (...) Jestem bojownikiem, chociaż pochodzę z dobrej rodziny, zdobytem wykształcenie i nienawidzę zabijania. Chcę się ożenić i mieć dzieci. I właśnie dlatego walczę: żeby móc żyć. Wiem jednak, że rewolucja została zinfiltrowana i że otaczaja nas wrogowie. (...) Czasami czuję się tak, jakbym byt pionkiem, ale co moge zrobić? ${ }^{34}$. Wiele z tych odczuć można by przypisać Bassetowi, który również przystąpił do rewolucji z wiarą w jej szybkie i pozytywne dla ludzi zakończenie. Wydawało mu się, że po zwycięstwie z łatwością będzie mógł powrócić do normalnego życia, później okazało się, że liczne rany, jakie odniósł nie pozwolą mu już nigdy na uprawianie futbolu, a pośród gruzów trudno będzie odtworzyć warunki wcześniejszej egzystencji.

Talal Derki po raz kolejny podjął temat wojny w Syrii w filmie $O$ ojcach $i$ synach (2017), opowiadając w nim o sposobach wychowywania chłopców do tego, by stali się w przyszłości żołnierzami ISIS. Sposób, w jaki reżyser przedstawił sytuację w poznanych przez siebie rodzinach arabskich wojowników, sprawia, że wyeksponowane zostały przede wszystkim relacje między mężczyznami. Tymczasem patriarchalizm, szczególnie radykalny w warunkach wojennych, dotyczy także kobiet - żon tytułowych ojców i matek rodzących się synów. One również ponoszą konsekwencje przeciągającego się konfliktu. Jak zwraca uwagę Samar Yazbek: Na prowincji tożsamość kulturowa mieszkańców tworza zwyczaje i tradycja, i jeśli kobiety cierpiaty tam z powodu prześladowań, wojna jeszcze to pogłębiła. Pojawity się ISIS (...) i inne ekstremistyczne bataliony dżihadystów, narzucajacych dalsze obostrzenia, których skutkiem było ograniczanie roli kobiet. Marzylyśmy - wcią̇ marzymy - o oporze ${ }^{35}$.

Dla bohaterki filmu $W$ czterech ścianach życia (Insyriated, 2017) formą oporu jest codzienna walka o przetrwanie w bombardowanym Damaszku, pozostającym w centrum konfliktu od czasów rozpoczęcia Arabskiej Wiosny. Chociaż zdjęcia zostały nakręcone w Libanie, w bejruckim mieszkaniu, to i tak belgijskiemu reżyserowi Philippe'owi Van Leeuwowi udało się wykreować napięcie, w jakim żyją ofiary toczącej się wojny. Oryginalność obrazu polega na odrzuceniu „obiektywnej” perspektywy i pokazaniu syryjskich wydarzeń z punktu widzenia rodziny chroniącej się w zabarykadowanym mieszkaniu przed nalotami i ostrzałem. Na ekranie nie ma więc ani panoram zrujnowanego miasta, ani ujęć walczących żołnierzy. Do oddania grozy wojny wystarczą niemal statyczne kadry opustoszałego podwórza, podglądanego przez szpary w zasłoniętych oknach. Widok staje się szczególnie dramatyczny, gdy za wrakiem samochodu pojawi się ciało postrzelonego przez snajpera mężczyzny, któremu nie sposób udzielić pomocy z obawy o życie ewentualnych ratowników. Największe wrażenie wywołuje kontrast między pustką prawie całkowicie wyludnionej okolicy i budynków a intensywnością odgłosów walk, docierających do ukrywających się cywilów. Natężenie wybuchów i innych wrogich dźwięków nie pozwala zapomnieć o trwającej wojnie, w trakcie której przestrzeń domu jest równocześnie schronieniem i pułapką bez wyjścia. Samar Yazbek próbowała opisać strategie przetrwania mieszkańców Sarakiby: $W$ schronie skrywaty się z nami także inne rodziny, większość z nich nie miała własnej kryjówki. Byli też z nami mieszkańcy domu, który stat na wprost stanowiska snajpera. Widziałam ten budynek: kule podziurawity mury. Kiedy tam poszłam i wymieniałam pospieszne uwagi z gospodynia, powiedziała mi, że gdy przechodzi przez dziedzi- 
niec, przystaje na moment i obserwuje snajpera. Udaje, że go nie zauważa, po czym biegnie po szklanke wody, obiad dla dzieci albo po prostu do toalety. - Zupetnie jakbym grała w jakąś grę z tym sukinsynem - powiedziała ze śmiechem ${ }^{36}$.

W filmie $W$ czterech ścianach życia mieszkanie bohaterki, żony walczącego żołnierza, staje się przystanią dla całej rodziny oraz pary sąsiadów, którzy schronili się w nim z nowo narodzonym dzieckiem. Kobieta stara się wszystkimi zaopiekować i zapewnić im namiastkę normalności, dbając o regularne posiłki i porządek. Podobne sytuacje pojawiają się w zapiskach Samar Yazbek, charakteryzującej wygląd jednej z mieszkanek zbombardowanej okolicy: Miata na sobie kwiecista chustke $i$ dtuga do kostek wzorzysta sukienke $w$ tropikalne kwiaty. Wszystkie kobiety tutaj nosity długie sukienki, ale na tle zniszczonego domu jej strój wydawat się zdumiewajaco barwny. (...) W jej domu byto catkiem pusto; tylko dywan zaściełat podtogę pokoju ${ }^{37}$. Bohaterom filmu Philippe'a Van Leeuwa coraz trudniej utrzymać pozory normalności, bowiem ogarnia ich paraliżujący strach, narastający z każdym wybuchem, wystrzałem, a także odgłosem kroków, zwiastujących najczęściej grasujących rabusiów. Zablokowane drzwi i okna dają tylko złudzenie bezpieczeństwa, znacznie ważniejsza jest siła i determinacja, jaką emanuje postać matki, odgrywającej rolę opiekunki i strażniczki. Reżyser obsadził w tej roli pochodzącą z Izraela Hiam Abbass, aktorkę o arabskich korzeniach, kojarzącą się z rolami silnych kobiet o mocnym charakterze, które potrafią zmierzyć się z tragiczną sytuacją. Taką właśnie postać stworzyła między innymi w swoim debiucie reżyserskim Iheritance (2012), w którym rodzinny dramat rozgrywał się na tle konfliktu zbrojnego między Izraelem a Libanem. W notatkach Samar Yazbek wielokrotnie pojawiają się postacie kobiece mające rysy bohaterki filmu Insyriated, jak na przykład Nura, której mąż przyłączył się do pokojowych demonstracji, a później walk: Ani on, ani Nura nigdy nie przestali wspierać rewolucji ani stużyć pomoca miejscowym rodzinom, które znalazły się w potrzebie. Damasceńczycy mówili na takie kobiety jak Nura „perfekcjonistki”. Wszystko, co robiła, musiało być idealne. Podczas bombardowania roznosiła na tacy szklanki wody i przygotowywała słodkie przekaski oraz kawę, $w$ małych, zdobionych złota lamówka filizankach ${ }^{38}$.

Twórcom Insyriated nie zależało na ukazaniu świata na zewnątrz, bowiem zamknięcie bohaterów w jedynym zamieszkanym w okolicy lokum wystarczyło dla stworzenia atmosfery nieustannego zagrożenia. Niebezpieczeństwo czyha na cywilów i ze strony snajperów, i bezkarnych band grabieżców, gotowych zgwałcić każdą napotkaną kobietę. Ich ofiarą staje się matka niemowlaka, chcąca swoją obecnością w pustym salonie odciągnąć uwagę włamywaczy od rodziny ukrytej w pomieszczeniu gospodarczym. Sytuacja, w której ludzie kierują się przede wszystkich strachem o życie swoje i najbliższych, rodzi nieustanne napięcia, wynikające z konieczności podejmowania radykalnych decyzji, na przykład czy pozostać w ukryciu czy ratować leżącego na podwórzu postrzelonego sąsiada? Reżyser nie daje jednoznacznych odpowiedzi, nie osądza, pokazując zróżnicowaną skalę emocji i różnorodność często zaskakujących postaw swoich bohaterów. Samar Yazbek ze szczegółami opisuje podobne doświadczenia, które zmuszają do współpracy rodziny i sąsiadów próbujących podtrzymać społeczne więzi w realiach wojny: Schron stanowiło przestronne pomieszczenie, wykorzystywane wcześniej przez rodzine jako schowek na narzędzia i tym podobne rzeczy. Jedne drzwi zaklejono kawatkami plastiku, gdyż jak powiedziała mi Manal, pewnego razu do środka 
wpadty odłamki. W schronie ukrywaty się głównie kobiety z dziećmi i tylko kilku mężczyzn. Reszta została na górze z krewnymi w podeszłym wieku ${ }^{39}$. W kontekście wydarzeń opisywanych przez Yazbek i przywołanych w scenariuszu filmu polski tytuł $W$ czterech ścianach życia brzmi nazbyt optymistycznie, bohaterowie wydają się bowiem tkwić w czterech ścianach śmierci, bez możliwości ucieczki czy skutecznej obrony.

Fabularną wizję życia ofiar konfliktu w Insyriated można także interpretować w oderwaniu od bieżących wydarzeń jako metaforyczny obraz zachowań ludzi w sytuacji kryzysowej. Podobnej uniwersalizacji nie da się dokonać wobec dokumentu Ferasa Fayyada Ostatni w Aleppo (2017), ukazującego życie syryjskiego miasta, które staje się celem intensywnych ataków zbrojnych przeciwko zwolennikom rewolucji. Reżyser podporządkował rytm opowieści nalotom i bombardowaniom utrzymującym mieszkańców w ciągłym strachu o rodzinę i dom, który w każdej chwili może legnąć w gruzach i pogrzebać w swoich lokatorów. W tak ekstremalnej sytuacji niezbędna okazuje się solidarność społeczna i wzajemna pomoc, którą starają się zapewnić członkowie Syryjskiej Obrony Cywilnej, tzw. Białych Hełmów, powstałej w 2013 r. Zalążkiem ochotniczej organizacji były oddziały ratownicze tworzone już w 2012 r., kiedy nasiliło się bombardowanie miast i osiedli syryjskich. O tym etapie walk pisze Samar Yazbek: Za dnia nie można było mówić o powtarzalności ostrzału, lecz noc zapowiadała rutynę. Pojedyncza bomba spadała mniej więcej co pót godziny, godzinę. W minionych trzech dniach spadło około stu trzydziestu bomb. Manal, żona Majsary, powiedziała mi, że od wybuchu rewolucji ani razu porządnie się nie wyspali. Mogli przespać najwyżej godzinę, po czym budziła ich eksplozja. Chodzili z błędnym wzrokiem ${ }^{40}$.

W filmie Fayyada motyw Białych Hełmów jest pretekstem do ukazania codziennej, społecznej strony niekończącego się konfliktu. Khaled Umar Harah i Mahmud to tylko dwaj mężczyźni spośród „ostatnich w Aleppo”, wolicjonalnie podejmujących się zadań ostrzegania przed nalotami lub, znacznie częściej, usuwania ich skutków i wykopywania spod gruzów ocalonych oraz trupów. Najczęściej powtarzającym się ujęciem jest widok biegnących mężczyzn, którzy zerwani na nogi przez dźwięk syren, pędzą do najbliższego pojazdu, by jak najszybciej interweniować. Jeden z nich przyznaje, że chciałby jeszcze kiedyś móc beztrosko patrzeć w niebo, bez konieczności wypatrywania nadlatujących samolotów. W realiach politycznych, w których powstawał dokument, nic nie wskazywało, że szybko będzie to możliwe, wręcz przeciwnie, ataki nie ustępowały, skazując członków Syryjskiej Obrony Cywilnej na życie w stanie ciągłej gotowości. Napięcie, w jakim żyją bohaterowie, przeżywający skrajne emocje - euforyczną radość albo bezdenną rozpacz, odzwierciedla kompozycja filmu, polegająca na montowaniu ze sobą skontrastowanych scen: codziennych zajęć i frontowych akcji. Mimo że ulice Aleppo zostały przekształcone w pole bitwy, bastiony i barykady, okopy i bunkry, pozostałe w mieście rodziny próbują nadal funkcjonować: wychowywać dzieci, dbać o dom, który bardziej niż kiedykolwiek ma stanowić przyjazne i bezpieczne schronienie. Na ten aspekt wojennego życia zwróciła także uwagę Samar Yazbek, gdy odwiedzała syryjskie wdowy na zbombardowanej prowincji: Niezwykle uderzajace byto to, że wszystkie domy (...) byty bardzo czyste. (...) wszędzie unosit się zapach środków czystości, nawet w najuboższych domach czuć było tanie mydło. Także w biednych przesiedlonych ro- 
dzinach, żyjacych w na poły zawalonych, bliskich ruiny budynkach kobiety dbały o czystość, nieustannie ścierały kurze zużytymi szmatkami, wilgotnymi ręcznikami ocieraty dzieciom buzie ${ }^{41}$.

Wysiłek wkładany przez mieszkańców Aleppo w podtrzymywanie domowych enklaw jest tym bardziej przejmujący, gdy widać, jak łatwo mogą one przestać istnieć. Z jednej strony Khaled jawi się jako oddany, opiekuńczy ojciec, którego cieszy każda chwila spędzona $\mathrm{z}$ bliskimi, zabawa $\mathrm{z}$ dziećmi, rozmowa $\mathrm{z}$ córką Batul o szkole (nadal funkcjonującej) i jej nauczycielce. $Z$ drugiej strony jest nieustannie świadkiem tragicznych wydarzeń, podczas których giną rodziny podobne do jego własnej. Dlatego w krótkich emocjonalnych wypowiedziach dzieli się swoimi obawami o najbliższych, skazanych na życie pod ostrzałem, przed którym nie mają gdzie uciec.

W swoim telefonie Khaled przechowuje nagranie z akcji ratunkowej, podczas której udało mu się uratować niemowlę ocalałe pod gruzami budynku. Pokazuje je także kilkuletniej Batul, która w bohaterskim ratowniku z dumą rozpoznaje ojca, nie widząc w tej sytuacji realnego zagrożenia. Dla mężczyzny krótki amatorski zapis jest dowodem na rangę służb cywilnych, a jego ponowne oglądanie pomaga mu podtrzymać wiarę w sens podejmowanych działań. Członkowie Białych Hełmów starają się zachować w pamięci budujące i napawające optymizmem chwile, aby móc poradzić sobie z poczuciem bezradności, jakie towarzyszy wielu akcjom odgruzowywania ulic i posesji. Po nieudanych interwencjach swoją rozpacz odreagowują najczęściej samotnie, płacząc lub zamykając się w sobie, a ich obsypane pyłem twarze sprawiają wrażenie zamaskowanych. Podobne zachowania i stany emocjonalne, od odwagi do obojętności, zaobserwowała Samar Yazbek, opisując moment zbombardowania trzykondygnacyjnego budynku, z którego ocalała tylko jedna dziewczyna. W eksplozji straciła matkę i brata; ojciec uniknął śmierci tylko dlatego, że na chwilę wyszedł z mieszkania, po powrocie mógł tylko pomagać w wydobywaniu zwłok oraz w poszukiwaniach najmłodszej, czteroletniej córki. Akcja przybrała dramatyczny wymiar: Muhammad wytonit się z ruin, niosac plastikowa kaczuszkę. (...) Kiedy unióst zabawkę, doleciat nas dziwny dźwięk. Nacisnąt kaczuszkę, która zakwakała. - To łamie mi serce. Szukamy dziewczynki pod gruzami, a tymczasem znajduję to... Jej kaczuszkę... Po tych stowach odszedt na chwile na bok ${ }^{42}$.

Tytuł Ostatni w Aleppo zwraca uwagę na zbiorowego bohatera filmu, którym są wszyscy pozostali na miejscu ocalali mieszkańcy miasta. Mimo że Fayyad skupił się w swojej opowieści na dwóch wolontariuszach z Białych Hełmów, to potraktował ich jako reprezentantów pewnej społecznej postawy opartej na sile przetrwania i poczuciu grupowej odpowiedzialności. Akcja toczy się w piątym roku konfliktu, a postawa bohaterów-cywilów przypomina bojowników, o których pisała Yazbek: Pozostali mężczyźni także odmówili wyjazdu (...) - wszyscy sa wierni swojemu marzeniu o pozostaniu w kraju. Zakres ich zadań się zmienit, ale wszyscy powtarzaja jak mantrę: „, Umrzemy tutaj. Nigdy nie wyjedziemy. To nasza ojczyzna”. Nie poddadza się - mówiq ${ }^{43}$. Rodziny z Aleppo również starają się nie poddawać $\mathrm{w}$ walce o przetrwanie i podtrzymanie więzi rodzinnych i społecznych.

\section{Komentarze do wydarzeń}

Ani filmowe, ani medialne obrazy Arabskiej Wiosny nie pomagają w jej jednoznacznej ocenie, o tyle trudnej, że rozpoczęte w 2011 r. konflikty miały różny 
przebieg i konsekwencje w każdym z krajów regionu. W swoim eseju Fouad Ajami użył dla okresu rewolucji określenia rok niebezpiecznego życia ${ }^{44}$, opisując, jak młodzi ludzie w poszukiwaniu wolności politycznej oraz szansy ekonomicznej, zmęczeni budzeniem się dzień po dniu w tej samej nudzie, podnieśli się przeciwko swoim sklerotycznym panom ${ }^{45}$. Podkreślił przy tym masowość i spontaniczność tego zrywu, zaznaczając, iż był on nieoczekiwanym wydarzeniem na Bliskim Wschodzie, gdzie tyrani zamknęli świat polityczny, stając się właścicielami swoich krajów, może tylko poza ich nazwą. (...) Arabowie zaczęli się czuć, jakby byli przeklęci, skazani na despotyzm ${ }^{46}$. Należy więc pamiętać, że powszechna oddolna mobilizacja krajów arabskich była wynikiem nie tylko sprzeciwu wobec panujących reżimów, ale też społeczną potrzebą odzyskania podmiotowości i poczucia sprawczości. Talal Derki po nakręceniu Powrotu do Homs stwierdził, iż mimo emocjonalnego ciężaru doświadczeń towarzyszących realizacji docenia wagę wydarzeń oraz swojego w nich udziału. Jego zdaniem: Syryjska rewolucja jest fenomenem, jaki może się ponownie nie zdarzyć na przestrzeni stu lat. Jednak powiedziałbym, że szczęściarzami sq następne pokolenia, pokolenia, które będa $\dot{z} y l y$ w lepszej Syrii ${ }^{47}$.

Równie trudno dokonać syntetycznego podsumowania poetyki filmów o Arabskiej Wiośnie oraz wymowy zawartych w nich obrazów. Można za to próbować odnaleźć w postawach reżyserów, zaangażowanych w protesty i wojenne działania, te cechy, o których pisze Samar Yazbek w swoich bezpośrednich relacjach: Kiedy jest się w środku rewolucji, zdolności analityczne nie sa koniczne; nie trzeba wiedzieć, jak skończy się dzień. Wystarczy mieć żelazne nerwy i stale być na bieżaco, umieć błyskawicznie lokalizować wyjścia awaryjne i trzymać się jak najdalej od stref bombardowania - co właściwie jest niemożliwe (...). Należy też zwracać uwagę na najdrobniejsze szczegóty i umieć wziać się w garść w obliczu okaleczonych ludzkich ciat $i$ zdewastowanych domów, nie zapominajac ani na moment, że nasze załamanie tylko utrudni życie innym ${ }^{48}$. W podsumowaniu swojej książki o powrotach do ogarniętej wojną Syrii Yazbek stwierdza: Oto zaledwie kilku bohaterów jednej z największych tragedii XXI wieku - a ich cierpienie jest przyttaczajacym dowodem na moralny upadek ludzkości. Ludzie ci wywołali rewolucje, marzac o wolności i sprawiedliwości. Niespetnione marzenia przypłacili krwia ${ }^{49}$. To samo można powiedzieć o bohaterach filmów, których twórcy starali się dokonać takiego zapisu wydarzeń Arabskiej Wiosny, by ich wymiar polityczny nie przytłoczył aspektów społecznych i humanitarnych.

MAŁGORZATA RADKIEWICZ

${ }^{1}$ Zob. Arab Spring in Egypt: Revolution and Beyond, red. B. Korany, R. El-Mahdi, American University in Cairo Press, Cairo 2012, s. 7.

${ }^{2}$ N. Bahlawan, Arabska Wiosna w Syrii i jej reperkusje w regionie Bliskiego Wschodu, ,Krakowskie Studia Międzynarodowe"2012, nr 1, s. 166.

${ }^{3}$ N. Sika, Dynamics of a Stagnant Religious Discourse and the Rise of New Secular Move- ments in Egypt, w: Arab Spring in Egypt... dz. cyt., s. 63.

${ }^{4}$ Zob. L. Anderson, Demystifying the Arab Spring, „Foreign Affairs” 2011, nr 90 (3), 20, s. 2-7.

${ }^{5}$ P. Norris, The Impact of Social Media on the Arab Uprisings: The Facebook, Twitter, and YouTube Revolutions? Odczyt wygłoszony na sympozjum Advancing Comparative Political 


\section{MAŁGORZATA RADKIEWICZ}

Communication Research: New Frameworks, Designs and Data, European Consortium Joint Workshops, Antwerp, Belgium, April 2012. Zob. G. Wolfsfeld, E. Segev, T. Sheafer, Social Media and the Arab Spring: Politics Comes First, ,The International Journal of Press/Politics" 2013, nr 18(2), s. 118.

${ }^{6} \mathrm{~S}$. Yazbek, A Woman in the Crossfire: Diaries of the Syrian Revolution, thum. $\mathrm{z}$ arabskiego M. Weiss, Haus Publishing, London 2012.

${ }^{7}$ R. Schami, Forward, w: tamże, s. 1.

${ }^{8}$ Tamże.

${ }^{9}$ Tamże, s. 3.

${ }^{10}$ Tamże.

${ }^{11}$ J. Speno, Tamer El Said: „I wanted to capture the soul of Cairo" (In „, The Last Days of the City”), „Diacritik.com” 2017, 9 października, 2017, https:/diacritik.com/2017/10/09/tamer-elsaid-i-wanted-to-capture-the-soul-of-cairo-inthe-last-days-of-the-city/ (dostęp: 27.02.2019).

12 Tamże.

${ }^{13}$ Tamże.

${ }^{14}$ Zob. M. Tarnawski, Międzynarodowe implikacje Arabskiej Wiosny, ,Przegląd Politologiczny" 2014, nr 1, s. 21.

${ }^{15} \mathrm{~J}$. Speno, dz. cyt.

${ }^{16}$ A. M. Lesch, Breeds Corruption, Repression, and Resistance, w: Arab Spring in Egypt... dz. cyt., s. 17.

17 J. Maswood, U. Natarajan, Democratization and Constitutional Reform in Egypt and Indonesia: Evaluating the Role of the Military, w: Arab Spring in Egypt... dz. cyt., s. 223.

${ }^{18}$ D. Bishara, The Power of Workers in Egypt's 2011 Uprising, w: tamże, s. 83.

19 Zob. S. Wollaston, Screenwriter David Farr on „The Night Manager”: , Le Carré invokes deep, almost religious ideas of betrayal, trust, and faith”, „The Guardian” 21.03.2016, https://www.theguardian.com/tv-andradio/2016/mar/21/night-manager-david-farrq-and-a (dostęp: 1.03.2019).

${ }^{20}$ Tamże.

${ }^{21}$ S. Yazbek, dz. cyt., s. 274.

${ }^{22}$ Zob. materiały prasowe do filmu, https://comingforthbyday.wordpress.com/ (dostęp: 27.02.2019).
${ }^{23}$ H. Sholkamy, Women Are Also Part of This Revolution, w: Arab Spring in Egypt... dz. cyt., s. 153.

${ }^{24}$ Zob. materiały prasowe do filmu. https://comingforthbyday.wordpress.com/ (dostęp: 27.02.2019).

${ }^{25}$ Zob. tamże.

${ }^{26}$ R. Schami, Forward, w: S. Yazbek, A Woman in the Crossfire... dz. cyt, s. 1.

${ }^{27}$ S. Yazbek, dz. cyt., s. 147.

${ }^{28}$ Tamże, s. 13.

${ }^{29}$ Tamże.

${ }^{30}$ Tamże.

${ }^{31}$ Zob. materiały prasowe do filmu Powrót do Homs, https://www.returntohoms.com/press (dostęp: 27.02.2019).

${ }^{32}$ G. Wolfsfeld, E. Segev, T. Sheafer, Social Media and the Arab Spring... dz. cyt., s. 116.

${ }^{33}$ Zob. materiały prasowe do filmu Powrót do Homs, https://www.returntohoms.com/press (dostęp: 27.02.2019)..

${ }^{34}$ S. Yazbek, dz. cyt., s. 150.

${ }^{35}$ Tamże, s. 226.

${ }^{36}$ Tamże, s. 27-28.

${ }^{37}$ Tamże.

${ }^{38}$ Tamże, s. 96.

${ }^{39}$ Tamże, s. 27.

${ }^{40}$ Tamże, s. 26-27.

${ }^{41}$ Tamże, s. 14.

${ }^{42}$ Tamże, s. 91.

43 Tamże, s. 275.

${ }^{44}$ F. Ajami, The Arab Spring at One. A Year of Living Dangerously, „Foreign Affair” 2012, nr 91 (2), https://www.foreignaffairs.com/articles/syria/2012-01-24/arab-spring-one (dostęp: 27.02.2019).

${ }^{45}$ Tamże.

${ }^{46}$ Tamże.

${ }^{47}$ Zob. materiały prasowe do filmu Powrót do Homs, https://www.returntohoms.com/press (dostęp: 27.02.2019).

${ }^{48}$ S. Yazbek, dz. cyt., s. 143-144.

${ }^{49}$ Tamże, s. 276. 